\title{
ADVIES GEVRAAGD!
}

Een 67-jarige patiënt wordt door zijn huistandarts verwezen met het verzoek het diasteem ter plaatse van element 21 te sluiten. $\mathrm{Er}$ is al op verschillende manieren geprobeerd het diasteem op te vullen, maar wegens een traumatische palatumbeet van element 33 is er geen duurzaam resultaat behaald. Een OPT (afbeelding 1) en intraorale lichtfoto's (afbeelding 2-5) tonen de complexe gemutileerde dentitie.

De mondhygiëne van de patiënt is uitermate ontoereikend (DPSI=2) en zodanig slecht dat zonder verbetering hiervan geen behandeling zal worden gestart.

Enkele maanden later blijkt dat behandeling door een mondhygiënist tot enige verbetering heeft geleid.
Er is nog wel wat plaque aanwezig, en er is nog sprake van bloedend tandvlees. De zelfzorg is echter dermate verbeterd dat een behandeling verantwoord lijkt.

Belangrijkste probleem is de uitgroei van de elementen in de zijdelingse delen aan de linkerzijde in het tweede en derde kwadrant. De patiënt wil niet dat er nog meer elementen worden verwijderd en heeft een beperkt budget tot zijn beschikking.

Onze vragen aan u, lezer, zijn:

1 Welke behandelmogelijkheden zijn hier nog mogelijk?

2 Waar zou u mee beginnen?

3 Hoe zouden de kosten van de behandeling beperkt kunnen blijven?

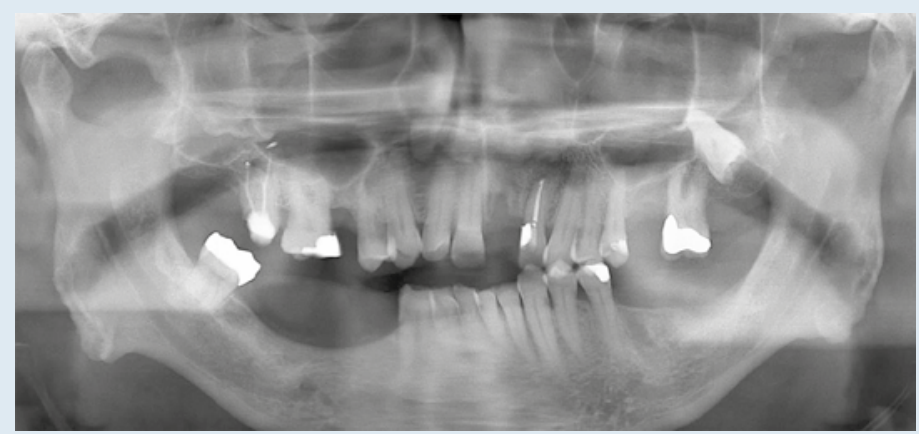

Afb. 1 De OPT.

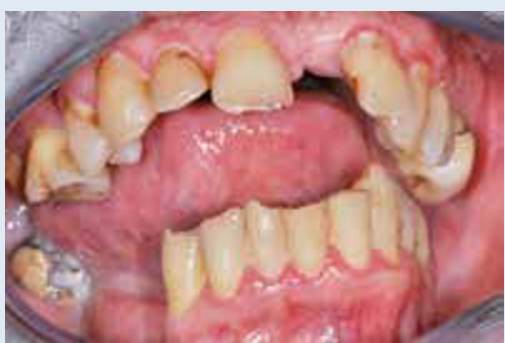

Afb. 2 Frontaal aanzicht waarbij te zien is dat de beet rechts open staat.
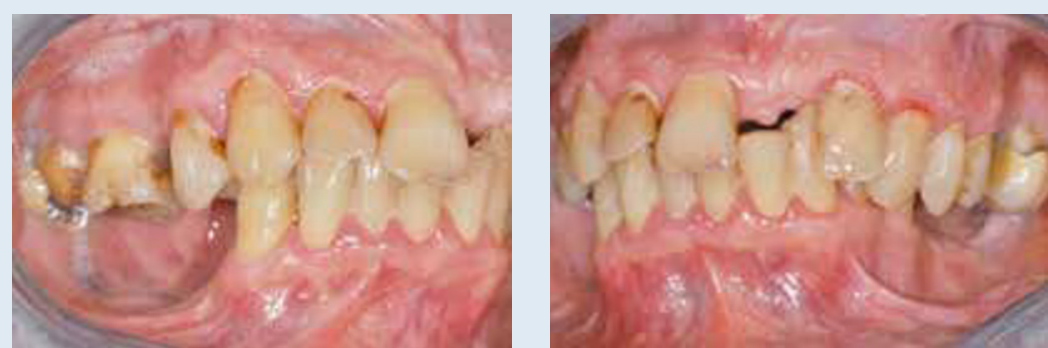

Afb. 3a-b Lateraal aanzicht laat zien dat de beet rechts openstaat als gevolg van uitgroei van het tweede kwadrant.

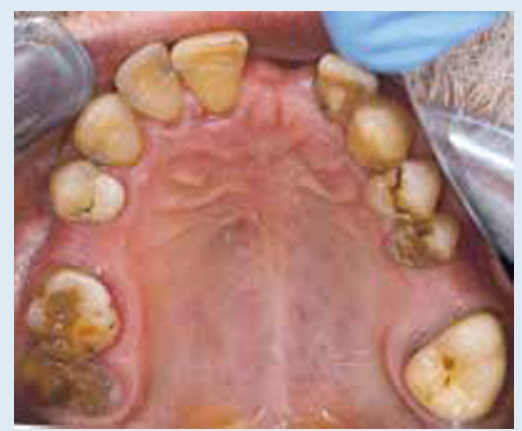

Afb. 4 Occlusaal aanzicht van de bovenkaak: niet alleen ter plaatse van de 21 is een diasteem te zien, maar ook de 15 en 26 ontbreken.

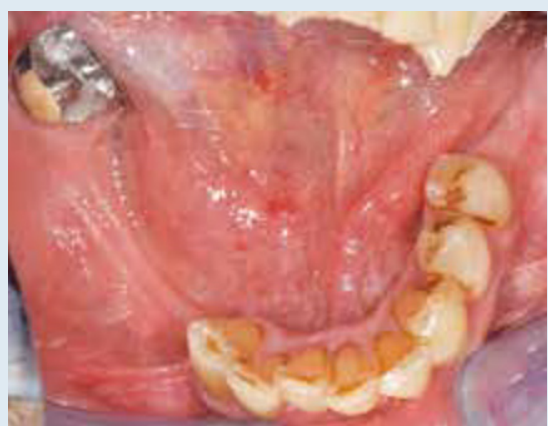

Afb. 5 Occlusaal aanzicht van de onderkaak: ook hier ontbreken een aantal elementen $(36,36$ en $44,45,46)$ waardoor er weinig antagonerende paren zijn. 